\title{
The Use of Negative Pressure Wound Therapy in Patients with Skin Grafts and Flaps
}

\author{
Prashant Moon* \\ Plastic and reconstructive surgeon, Krishna hospital and research centre, India
}

Submission: December 19, 2017; Published: January 26, 2018

*Corresponding author: Dr Prashant Moon, Plastic and Reconstructive surgeon, Krishna hospital and research centre , Haldwani, India, Tel: 9100423529; Email: prashantemoon@gmail.com

\begin{abstract}
Acute and Chronic wound management represents a considerable burden on health services and requires considerable manpower, frequent consultations and adjunct therapies. Chronic wounds affect patient's ability to function in their environment causing financial social and psychological consequences as well as affecting their quality of life. Regardless of etiology, wounds are difficult to treat if coexisting factors (e.g., infection or diabetes mellitus) prevent regular wound healing. Wounds represent a significant risk factor for hospitalization, amputation, sepsis, and even death, and from the patient's perspective, wound therapy is often uncomfortable or painful. Topical Negative pressure devices are believed to hasten the take of graft, removing wound exudates, increasing local blood flow, provide immobilization of graft, applying mechanical pressure to promote wound closure and reducing bacterial load in the wound. In addition to providing an optimal wound bed environment, topical negative pressure has been shown to increase local blood flow to the wound site in initial animal studies. Adequate perfusion is essential to proper take of the graft in order to provide nutrients and to remove inflammatory mediators to the wound and to remove local edema.
\end{abstract}

Keywords: Wound; Graft; Exudates; Negative Pressure

\section{Introduction}

Increasing the healing rate of a wound by applying an externally controlled negative pressure is known as Negative Pressure Wound Therapy (NPWT). Negative pressure drains serve as an excellent atmospheric bandage [1,2] and NPWT can be used for treating wounds which usually take a long time to heal or do not heal at all when treated using conventional treatment methods [3] and also diabetic foot disease which has become a major global burden [2]. Though, international organizations have already developed NPWT machines, their cost is around 7 to 8 thousand [4], which is unbearable to a developing country like India. Increasing healthcare costs and the growing burden of non-healing wounds is a challenging issue in India. Due to their high cost, NPWT devices are not available in Indian civil hospitals [5-7].

As a result, the patients with non-healing wounds Increases the healthcare cost of the country due to their long stays at hospitals and suffer changes in their life style. Especially, diabetic foot amputees lose their legs due to non-healing wounds. A manually operated low cost NPWT device was therefore developed at our General Hospital. It has demonstrated the success of the therapy to, many patients with non healing ulcers, traumatic raw area. In our hospital we have applied this system to patients operated with split thickness grafts and flaps. We have observed early take of graft and early settlement of flaps But one problem identified with this machine is that it is being operated manually and its inability to maintain pressure at a regular value, But the desired pressure range in NPWT is -50 to $-175 \mathrm{mmHg}$ while the optimal value is $-125 \mathrm{mmHg}$ [5]. objective of the this research is to develop a reliable, low power consuming, user friendly, portable and low cost NPWT system to treat different types of wounds and to Test the system clinically at a plastic surgery department to Evaluate its performance.

\section{Aims and Objective}

a. To study effect of Negative pressure wound therapy on post-operative Outcomes in Patients operated with skin graft and flap.

b. To study impact of negative pressure wound therapy on local infection.

c. To develop a manually operated low cost NPWT device.

d. To study duration of the graft take with use of the device.

\section{Materials and Methods}

This study is a single institutional observational cohort study of Negative Pressure Wound Therapy post operatively for the purpose of early graft take and early settlement of flap. Data will be prospectively collected in a standardized fashion. The analyzed preoperative variables include patient demographics, co morbid conditions, and laboratory values, culture and sensitivity of 
wound, site and condition of wound. After application graft and flap and application of negative pressure wound therapy patient will be observed for any local or systemic complication, wound contraction, progress of graft take length of hospital stay (LOS), wound condition, morbidity will be assessed [8-10].

\section{Indications for Use}

The Negative Pressure Wound Therapy System (NPWT) is an integrated wound management system for use in acute and extended settings. It is intended to create an environment that promotes wound healing by secondary or tertiary (delayed primary) intention by preparing the wound bed for closure, reducing edema [10], promoting granulation tissue formation and perfusion and by removing exudates and infectious material $[11,12]$. It is indicated for patients with chronic, acute, traumatic, sub-acute and dehisced wounds, partial-thickness burns, ulcers (such as diabetic, pressure or venous insufficiency), flaps and grafts. The Negative Pressure wound therapy is an effective barrier to bacterial penetration and may help reduce infection $[13,14]$.

\section{Contraindications}

Do not place foam dressings of the Negative Pressure Wound Therapy System directly in contact with exposed blood vessels, anastomotic sites, organs, or nerves. Negative Pressure Wound Therapy is contraindicated for patients with:
a. Malignancy in the wound
b. Untreated osteomyelitis
c. Non-enteric and unexplored fistulas
d. Necrotic tissue with eschar present
e. Vasculitis
f. HIV and HbsAg positive Patients
g. Sensitivity to products used in dressing

After debridement of necrotic tissue and complete removal of eschar, Negative Pressure Wound Therapy may be used.

\section{Mechanism of Action}

The Negative Pressure Wound Therapy is the first active, non-invasive wound care product, used by a secure local regulated sub-atmospheric pressure technique.

The exact mechanisms to explain this treatment are not known yet. Researches by Argenta et al. [12,13] postulated that interrelated factors are the basis for the success of the technique. These factors can be devised in 3 subgroups:

\section{Removing}

Tissues surrounding the chronic wounds are characterized by localized collection of interstitial or third-space fluid. This third space fluid or edema caused by increased capillary permeability in wound. Wound cell and nourishment of wound decrease due to Edema fluid oxygenation. This collection of third-space fluid contains factors which inhibits or suppresses mitosis, protein synthesis and fibroblasts collagen synthesis. An active withdrawal of this fluid removes the excess of third space wound fluid and its inhibitory factors. The active withdrawal also results in the removing of wound debris.

\section{Improving}

The collection of third space fluid mechanically compromises the micro-vascularisation and lymphatic system. By removing the third space fluid and its inhibitory factors, this result in increased vascularisation, reduced venous after load and an increased delivery of oxygen and nutrients as well. These changes improve the rate of granulation formation and the concentration of growth factors. An additional mechanism of the Negetive Pressure Wound Therapy is the mechanical stimulation of cells migration by tensile forces placed on the surrounding tissues [10]. Adequate wound perfusion essential for tissue repair. Blood supply required for delivery of cells, factors \& elements like Platelets, Neutrophils, Monocytes, Nutrients, and Oxygen etc. Peripheral blood supply essential for wound healing processes to continue. It Helps fight infection and Delivers oxygen \& nutrients for healing [11,12,13].

\section{Reducing}

Besides reducing of third space fluid, We know that successful wound healing correlates with bacterial counts of less than 1,00,000 organism per gram of tissue. Bacterial counts of human wounds treated by Negative Pressure Wound Therapy have demonstrated a significant decrease after 3-4 days usually until less than 1000 per gram of tissue $[14,15]$.

\section{NPWT for Split Thickness Grafts}

NPWT has been used instead of traditional bolstering methods to provide skin graft fixation. Improved qualitative skin graft take and quantitative improvement in skin graft success (e.g. repeat grafts) have been described in observational studies and two randomized trials [16,21]. Moisidis E \& Heath T, et al. [17] conducted a trial in which 60 patients are randomly assigned to NPWT dressing connected to An aspiration to NPWT dressing connected to aspiration system versus NPWT dressing not connected to an aspiration system after STSG. NPWT was associated with significant reduction in graft loss.

1. Loss of graft area: zero versus $4.5 \mathrm{~cm}^{2}$ in control group

\section{Median duration of hospital stay: 13.5 versus 17 days}

In our study, median duration of hospital stay was 11 days for split thickness skin graft with NPWT. Median duration of hospital stay was 13 days for flaps. Moisidis and colleagues compared a standard bolster dressing with an NPWT dressing, although quantitative graft take was similar between two groups but NPWT significantly improved the qualitative appearance of the graft. 


\section{NPWT for Flaps}

The usefulness of NPWT over vascularised flaps is controversial. Morgan and colleagues specifically reported that NPWT does not increase the risk of flap failure rates or complication. However NPWT has also been shown to reduce tissue edema and improve venous congestion and contouring of flaps all of which consider beneficial. Eisenhardt, et al. [18] specifically reported that NPWT does not increase the risk of flap failure rates or complication. In our study there was reduction of tissue edema and there is no flap failure with NPWT.

\section{Discussion}

In the present study of Use of Negative Pressure Wound Therapy in Post-operative Patients with Skin Grafts and Flaps, 30 cases admitted in our ward were studied. Maximum (90.0\%) numbers of patients in this study were males. Most of the patients admitted with soft tissue defect were suffered from road traffic accident and Most of the populations in road traffic accidents are males (Figure 1). In our study maximum number of population was between age group of 40 to 60 years (30\%), followed by young population between 10 to 20 years $(20 \%)$ and 20 to 30 years $(20 \%)$. Least number of patients is above 60 years of age (Figure 2). Causes aft raw area and soft tissue defect in our study was road traffic accident (73.33\%) followed by post cellulites raw area $(13.33 \%)$, post operative dehisced flaps $(6.66 \%)$ and chronic ulcers (6.66\%) (Figure 3).
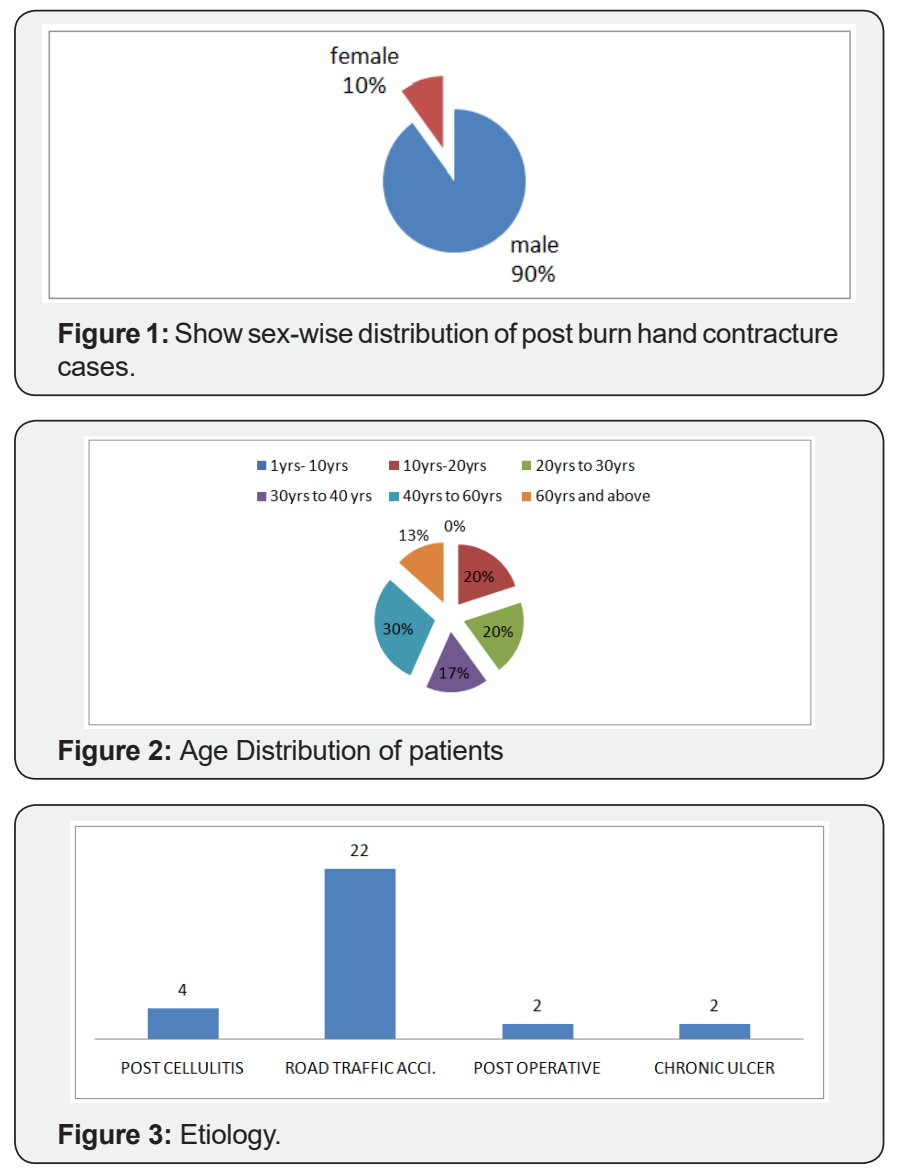

Maximum numbers of patient were having less than $50 \mathrm{~cm}^{2}$ (70\%) area for application of negative pressure wound therapy. Five patients are having surface area of 50 to $100 \mathrm{~cm}^{2}$. There are three patients with size more than $200 \mathrm{~cm}^{2}$ and one patient with size between 100 to $200 \mathrm{~cm}^{2}$ (Figure 4). In our study $63 \%$ patients are having good amount of healthy granulation over wound most of which achieved by pre operative application of negative pressure wound therapy. 36\% patients are having unhealthy granulation tissue (Figure 5). 93.33\% Patients treated with gauze application. $6.66 \%$ patients treated with presterilised foam application (Figure 6). Only one patient is having is having graft take less than $70 \% .41 \%$ patients are having graft take of a $100 \%$. 29\% patients are having graft take of $95 \%$. Patients having $90 \%$ and $80 \%$ of graft take are 12.5 percentages each (Figure 7).

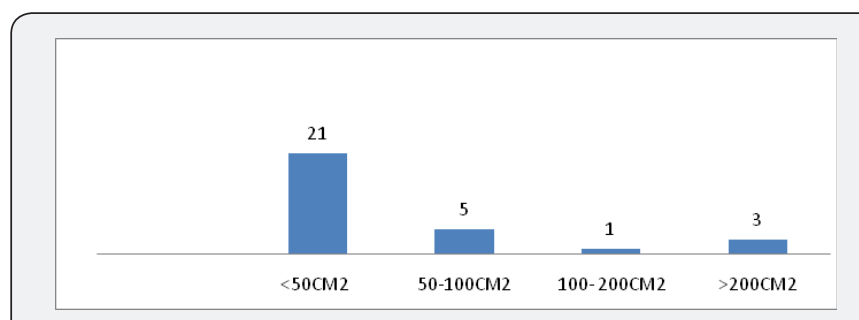

Figure 4: Surface Area for Application of NPWT.

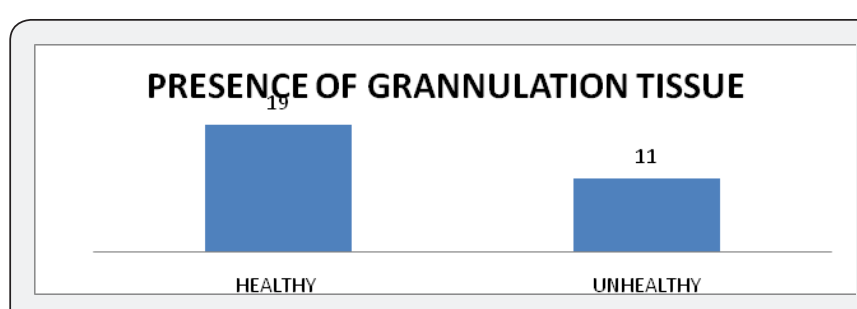

Figure 5: Shows incidence of different part of body involved in post burn hand contracture.

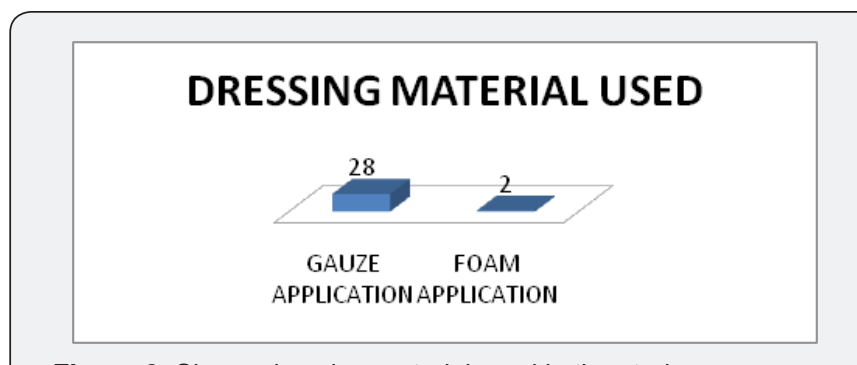

Figure 6: Shows dressing material used in the study.

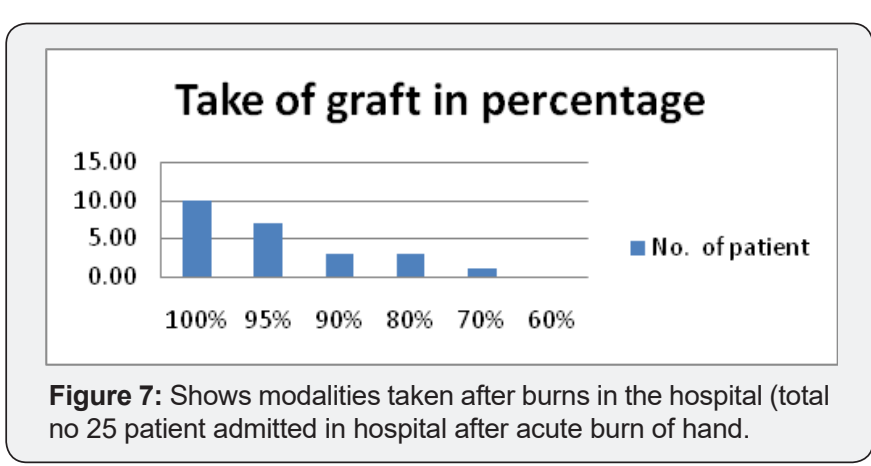




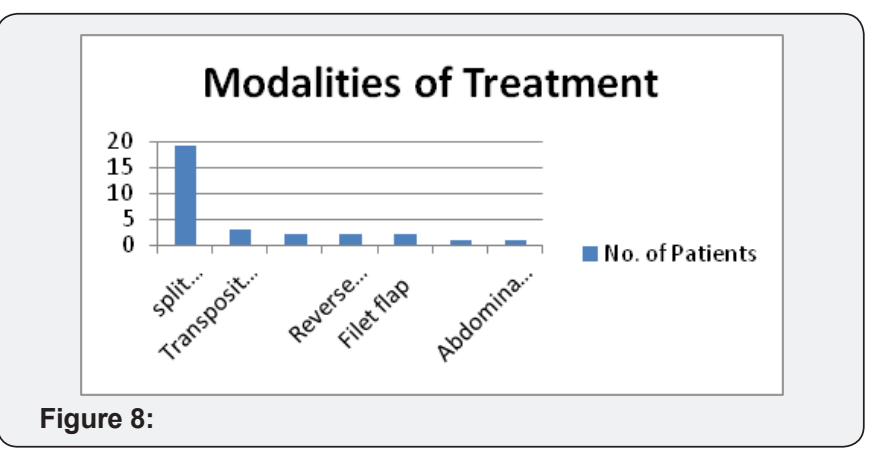

Maximum no. of patient treated with split thickness skin grafting [19] with excellent results. 3 patients were treated with

Table 1: Shows early post operative complication. transposition flap and application of negative pressure wound therapy to both transposition flap and adjacent graft, 2 patients were having gastrocnemius flap for upper third defect of leg. In 2 patients negative pressure wound therapy applied over reverse surely artery flap after division and inset. 2 patients are of fillet flap of great toe. In One patient NPWT applied over groin flap after division and inset and in one patient NPWT it is applied over abdominal flap after dehiscence of suture line after division and inset (Figure 8). 1 patient with split thickness skin grafting was having infection in scar, while 1 patient was having pain over dressing area. One patient with gastrocnemius flap was having skin rash at edge of flap area which is managed by daily dressing (Table 1).

\begin{tabular}{|c|c|c|c|c|c|c|c|}
\hline & $\begin{array}{c}\text { Split thickness } \\
\text { skin grafting }\end{array}$ & $\begin{array}{c}\text { Transposition flap } \\
\text { with graft over } \\
\text { secondary defect }\end{array}$ & $\begin{array}{c}\text { Gastrocnimus } \\
\text { flap with graft }\end{array}$ & DBSA FLAP & Filet flap & $\begin{array}{c}\text { Groin flap } \\
\text { after division } \\
\text { inset }\end{array}$ & $\begin{array}{c}\text { Abdominal flap } \\
\text { for dehisced } \\
\text { suture line }\end{array}$ \\
\hline $\begin{array}{c}\text { Infection/ } \\
\text { abscess }\end{array}$ & 1 & 0 & 0 & 0 & 0 & 0 & 0 \\
\hline Pain & 1 & 0 & 0 & 0 & 0 & 0 & 0 \\
\hline Bleeding & 0 & 0 & 1 & 0 & 0 & 0 & 0 \\
\hline $\begin{array}{c}\text { Peripheral skin } \\
\text { rash }\end{array}$ & 0 & 0 & 0 & 0 & 0 & 0 & 0 \\
\hline
\end{tabular}

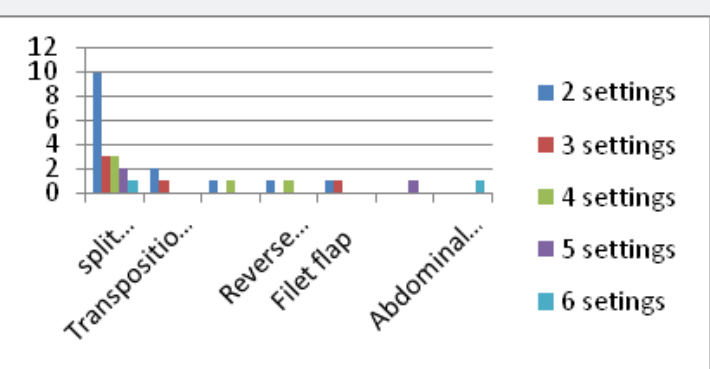

Figure 9: Settings of negative pressure wound therapy application in patient compared with different modalities of treatment.

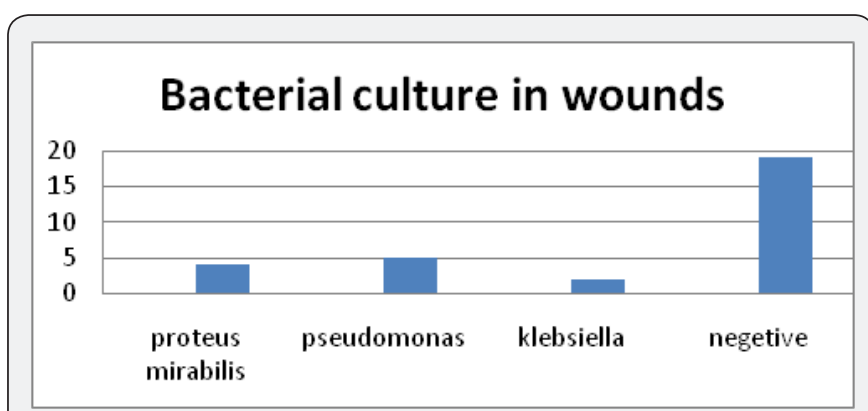

Figure 10: Shows bacterial cultures in patients underwent negative pressure wound therapy.

Maximum Patients with split thickness skin grafting were given 2 settings of negative pressure wound therapy each of 3 days $(50.00 \%)$ out of 24 patients (Figure 9). Out of 30 patients 19 patients (63.33) were having negative culture reports. 4 patients were having proteus mirabilis (13.33), 5 patients were having pseudomonas (16.66), 2 patients $(6.66 \%)$ were having klebsiella organism in there bacteriological culture. One patient with pseudomonas culture on raw area shoes graft take of $70 \%$. As end point of result was complete graft take and flap settlement there is no organism were found on bacteriological culture (Figure 10). Out of 19 patients with split thickness graft 16 patients((63.33\%) were treated with intermittent NPWT and 3 patients were treated with continuous NPWT. 9 patients (81.81\%) of flaps treated intermittent NPWT 2 patients were treated with continuous NPWT (Figure 11).

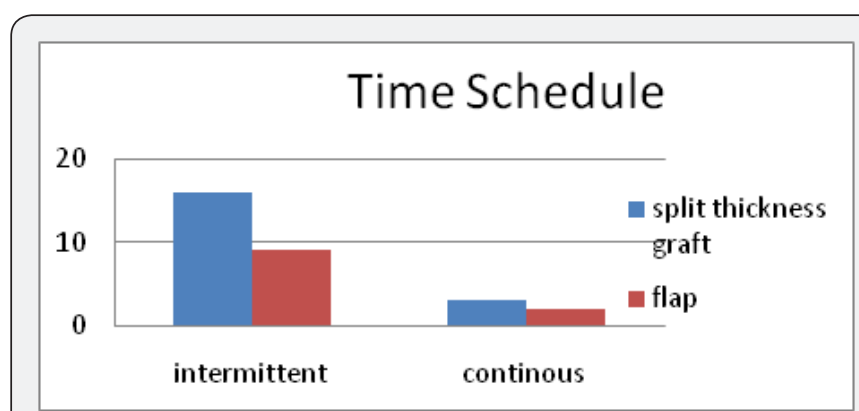

Figure 11: Shows time schedule of Negative Pressure Wound Therapy.

Acute and Chronic wound management represents a considerable burden on health services and requires considerable manpower, frequent consultations and adjunct therapies. Chronic wounds affect patient's ability to function in their environment causing financial social and psychological consequences as well as affecting their quality of life [1-6]. Regardless of etiology, wounds are difficult to treat if coexisting factors (e.g., infection or diabetes mellitus) prevent regular 
wound healing [22,23]. Wounds represent a significant risk factor for hospitalization, amputation, sepsis, and even death, and from the patient's perspective, wound therapy is often uncomfortable or painful. Topical Negative pressure devices are believed to hasten the take of graft, removing wound exudates, increasing local blood flow, provide immobilization of graft, applying mechanical pressure to promote wound closure and reducing bacterial load in the wound. In addition to providing an optimal wound bed environment, topical negative pressure has been shown to increase local blood flow to the wound site in initial animal studies. Adequate perfusion is essential to proper take of the graft in order to provide nutrients and to remove inflammatory mediators to the wound and to remove local edema. An important factor in wound healing is the growth of granulation tissue. Initial studies by Morykwas et al. [24,25,26] showed a significant increase in rate of granulation tissue formation in wounds treated with NPWT Device compared with control wounds treated with saline-moistened gauze.

Argenta et al. [22] reported finding from animal study as well as human clinics trials showing that a fourfold increase in blood flow levels when $125 \mathrm{mmHg}$ sub-atmospheric pressures was applied. A significantly increased rate of granulation tissue formation $(\mathrm{p}<=0.5)$ was reported with continuous $(63.3 \%$ $-/+26.1 \%)$ and intermittent $(103 \%-/+35.3 \%)$ application of negative pressure wound therapy.

\section{Complication}

Minimal complication encounters in present study. Bleeding occurs in one patient with operated case of gastrocnemius flap with application of NPWT over surface. There is a discontinuation in application of NPWT in one patient due to excessive pain. One of the patients with NPWT develops peripheral skin infection leading to discontinuation of NPWT [23]. Even unethical given the large effects observed in uncontrolled studies. Clinical and economical importance of NPWT has increased in recent times because it is an innovative and commercially successful concept for the management of difficult to treat wound of nearly every etiology $[19,20]$. The results of our study showed that indigenous NPWT is an effective tool in management of Split thickness graft, post surgical dehisced wounds and flaps. It is cost effective as compared to imported / local commercial NPWT devices available in the market. Indigenous NPWT is safe with minimal adverse events.

\section{Results}

A. Negative pressure wound therapy is cost effective as compared to commercially available negative pressure wound therapy.

B. Negative pressure wound therapy improve quantitative take of graft and decreases hospital stay.

C. Negative pressure wound therapy is useful option on dehisced flap to reduce edema and for early settlement of flap (Figures 12-25).

\section{Case 1}

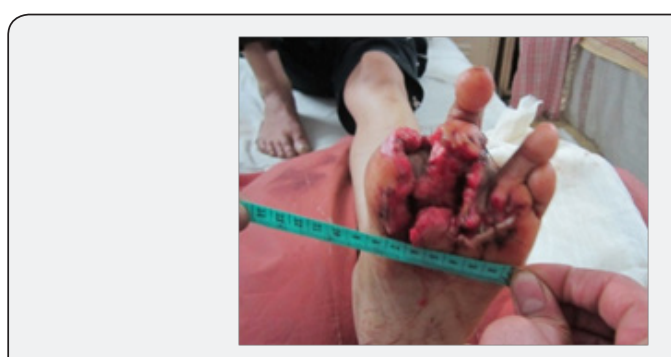

Figure 12: 28 year old male with known case of Hansen's disease operated with right great toe tropic ulcer. Patient operated with right first toe fillet flap. Dehiscence of fillet flap on day 3.

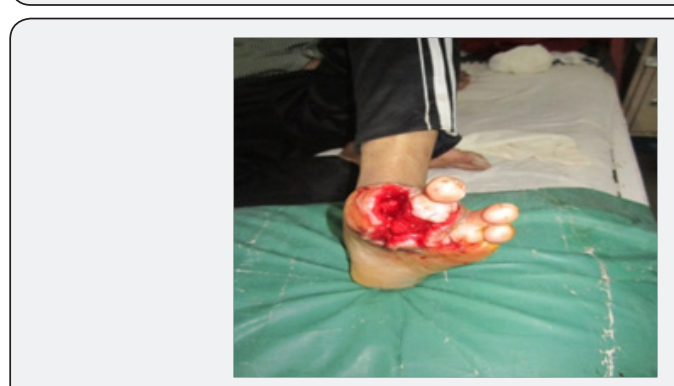

Figure 13: Preoperative application of NPWT.

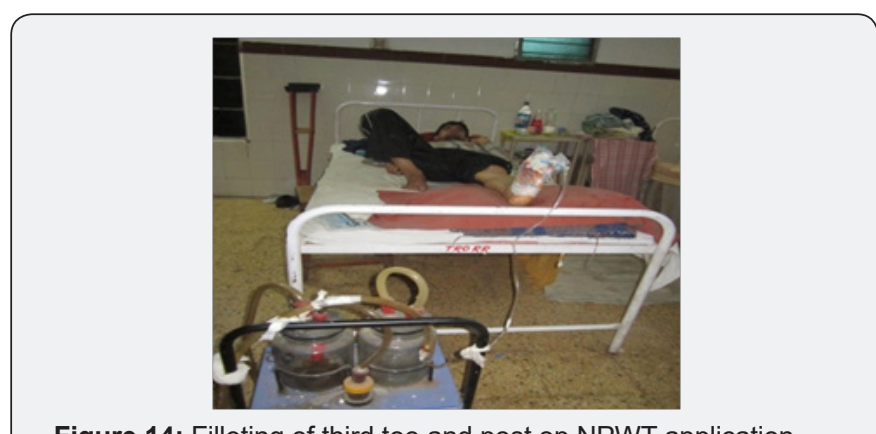

Figure 14: Filleting of third toe and post op NPWT application.

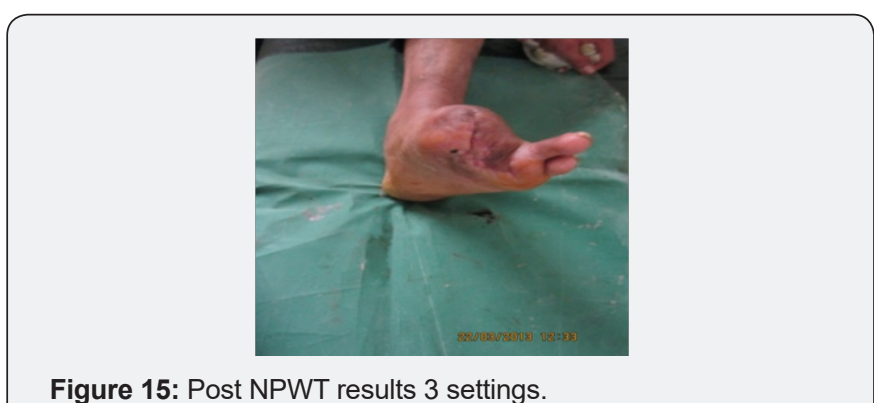

Figure 15: Post NPWT results 3 settings.

Case 2: 28 year old male with history of post traumatic raw area over dorsum of foot.

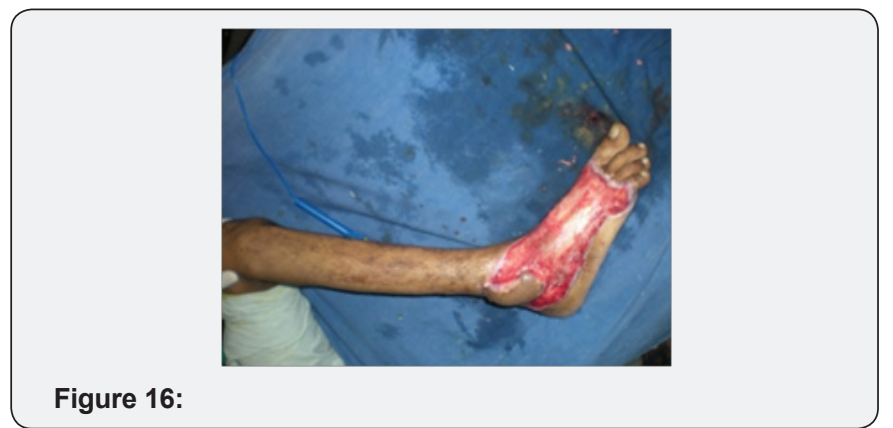




\section{Juniper Online Journal of Orthoplastic \& Microsurgical Reconstruction}
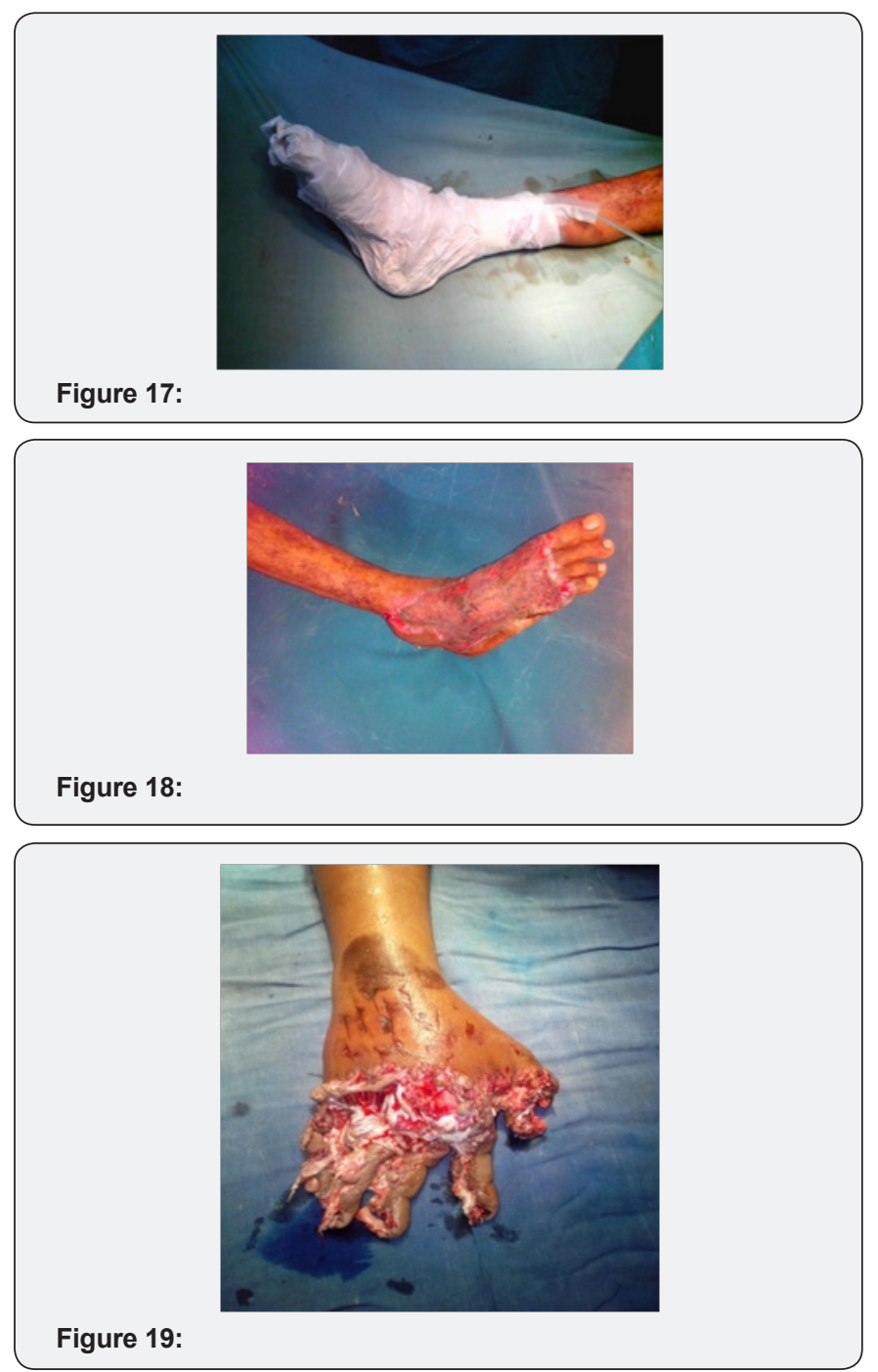

Case 3: Crush injury to right hand due to hand caught in ganna machine.

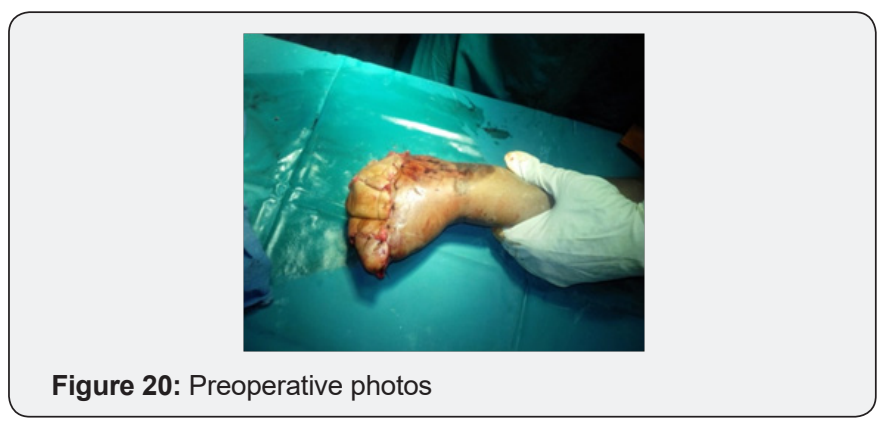

Figure 21: Filleting of volar skin flap done. NPWT applied over hand.

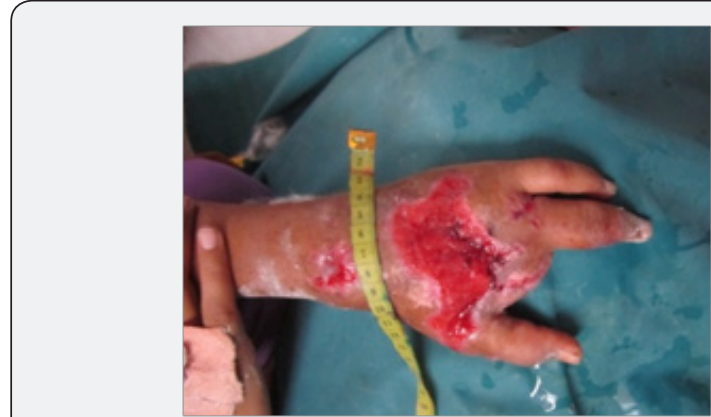

Figure 22: Post op results after 3 settings of NPWT.

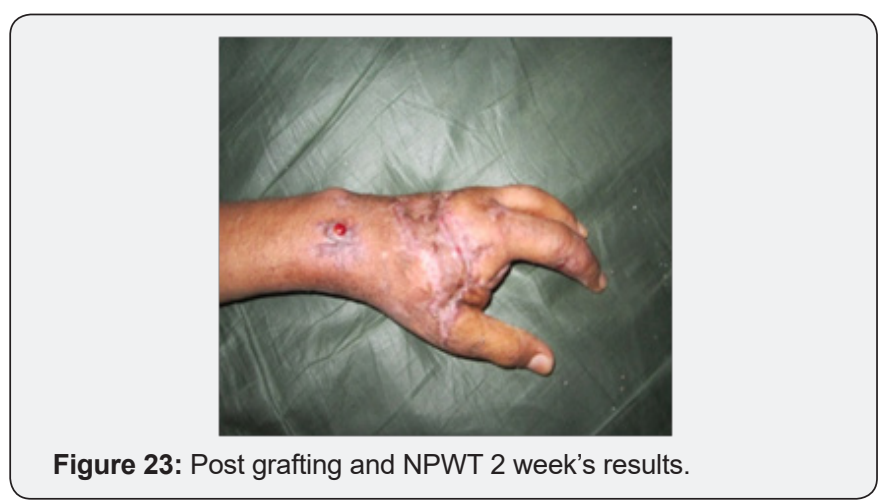

Case 4: Operated case of crush hand injury of right hand with filleting of second and third digit with raw area over dorsum of hand.
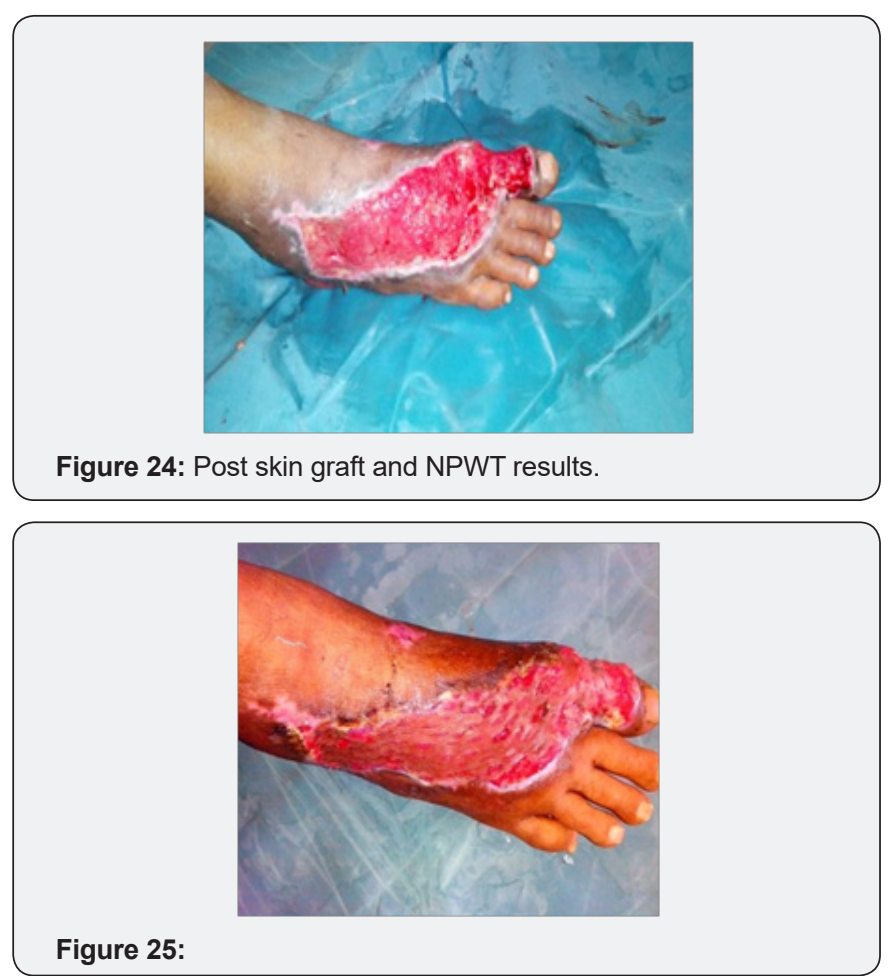

\section{Conflict of Interest}

None

\section{References}

1. Argenta L, Morykwas M (1997) Vacuum assisted closure: A new method for wound control and treatment: Clinical experience. Ann Plast Surg 38(6): 563-576. 
2. Cipolla J, Stawicki SP, Hoff WS, McQuay N, Hoey BA, et al. (2005) A proposed algorithm for managing the open abdomen. Am Surg 71(3): 202-207.

3. Cro C, George KJ, Donnelly J, Irwin ST, Gardiner KR (2002) Vacuum assisted closure system in the management of enterocutaneous fistulae. Postgrad Med J 78(920): 364-365.

4. Sjogren J, Gustafsson R, Nilsson J, Malmsjo M, Ingemansson R (2005) Clinical outcome after poststernotomymediastinitis: Vacuum-assisted closure versus conventional treatment. Ann ThoracSurg 79(6): 20492055.

5. Kutschka I, Frauendorfer P, Harringer W (2004) [Vacuum assisted closure therapy improves early postoperative lung function in patients with large sternal wounds]. Zentralbl Chir 129 Suppl 1: S33-S4.

6. Chariker ME, Jeter KF, Tintle TE, Bottsford JE (1989) Effective management of incisional and cutaneous fistula with closed suction wound drainage. Contemp Surg 34: 59-63.

7. Morykwas MJ, Argenta LC, Shelton-Brown EI, McGuirt W (1997) Vacuum-assisted closure: a new method for wound control and treatment: animal studies and basic foundation. Ann Plast Surg 38(6): 553-562.

8. Jeroen DD, Vuerstaek, Vainas T, Wuite J, Nelemans P (2006) State-ofthe-art treatment of chronic leg ulcers: A randomized controlled trial comparing vacuum-assisted closure (V.A.C.) with modern wound dressings. Journal of Vascular Surgery. 44(5):1029-1037.

9. Kinetic concepts Inc VAC therapy indication and contradications. (2016) Acelity.

10. O'Connor J, Kells A, Henry S, Scalea T (2005) Vacuum-assisted closure for the treatment of complex chest wounds. Ann Thorac Surg 79(4): 1196-200.

11. Dainty LA, Bosco JJ, McBroom JW, Winter WE 3rd, Rose GS (2005) Novel techniques to improve split-thickness skin graft viability during vulvo-vaginal reconstruction. Gynecol Oncol 97(3): 949-52.

12. deGeus HR, van der Klooster JM (2005) Vacuum-assisted closure in the treatment of large skin defects due to necrotizing fasciitis. Intensive Care Med 31(4): 601.
13. Mehbod AA, Ogilvie JW, Pinto MR, Schwender JD, Transfeldt EE, et al.(2005) Postoperative deep wound infections in adults after spinal fusion: Management with vacuum-assisted wound closure. J Spinal Disord Tech 18(1): 14-17.

14. Halama D, Hemprich A, Frerich B (2004) [Intraoral application of vacuum-assisted closure in the treatment of an extended mandibular keratocyst]. Zentralbl Chir 129 Suppl 1: S53-S56.

15. McCallon SK, Knight CA, Valiulus JP, Cunningham MW, McCulloch JM, et al. (2000) Vacuum-assisted closure versus saline-moistened gauze in the healing of the postoperative diabetic foot wounds. Ostomy Wound Manage 46(8): 28-32, 34.

16. Korber A, Franckson T, Grabbe S, Dissemond J (2008) Vacuum assiated closure device improves the take of mesh graft in chronic leg ulcer patients. Dematology 216(3): 250-256.

17. Moisidis E, Heath T, Boorer C, et al. (2004) A Prospective blinded, randomized, controlled clinical trial of topical negative pressure use in skin grafting. Plastic reconstructive surg 114(4): 917-922.

18. Eisenhardt SU, Moneni A,Iblher N, Penna V, Schmidt Y, et al. (2010) The use of the Vacuum-Assisted Closure in microvascular closure revisited: application in the reconstruction of the posttraumatic lower extremity. J Reconstr Microsurg 26(9): 615-622.

19. Greene AK, Puder M, Roy R, Arsenault D, Kwei S, et al. (2006) Microdeformational wound therapy: effects on angiogenesis and matrix metalloproteinases in chronic wounds of 3 debilitated patients. Ann Plast Surg 56(4): 418-422.

20. Shriakawa M.,Isseroff R (2005) Topical Negative Pressure Devices; Use for Enhancement of healing chronic wounds. Arch Dermatol 141(11): $1449-1453$

21. Stone P, Prigozen J, Hofeldt M, Stephen Hass, John DeLuca, et al. (2004) Bolster versus negative pressure Therapy for Securing Split-Thickness Skin Grafts in Trauma Patients 16(7).

22. Argenta and Morykwas, Morykwas (2004) Wound therapy for securing split-thickness skin grafts in trauma patients. Wounds 16: 219-223.

23. Saxena V, Hwang CW, Huang S, Eichbaum Q, Ingber D,Orgill DP (2004) Vacuum-assisted closure: Microdeformations of wounds and cell proliferation. Plast Reconstr Surg 114(5): 1086-1098.

\section{Your next submission with Juniper Publishers will reach you the below assets}

- Quality Editorial service

- Swift Peer Review

- Reprints availability

- E-prints Service

- Manuscript Podcast for convenient understanding

- Global attainment for your research

- Manuscript accessibility in different formats (Pdf, E-pub, Full Text, Audio)

- Unceasing customer service

Track the below URL for one-step submission https://juniperpublishers.com/online-submission.php 